\title{
Aves acuáticas de la Laguna de Agua Dulce y el Estero El Ermitaño, Jalisco, México
}

Salvador Hernández Vázquez

Departamento de Estudios para el Desarrollo Sustentable de Zonas Costeras. Universidad de Guadalajara. Gómez Farias No. 82, San Patricio-Melaque, Municipio de Cihuatlán, Jalisco, CP 48980. México. Fax: (335) 56331;

sahernan@costera.melaque.udg.mx

Este artículo se publicó en el Volumen 53, fascículo 1-2, correspondiente a los meses de marzojunio 2005. Por error se omitieron las figuras 1, 2 y 3 que se mencionan en su texto, las cuales se adjuntan en esta publicación.
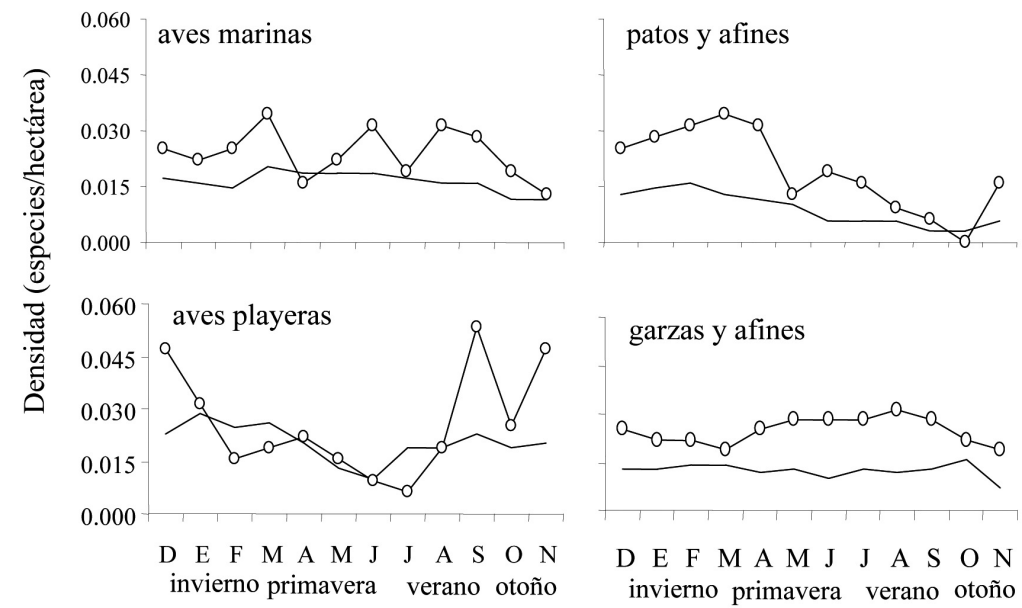

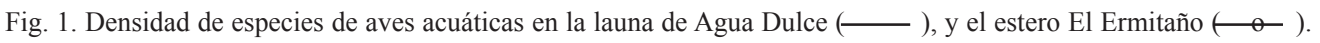

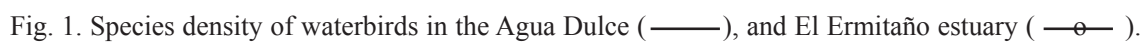




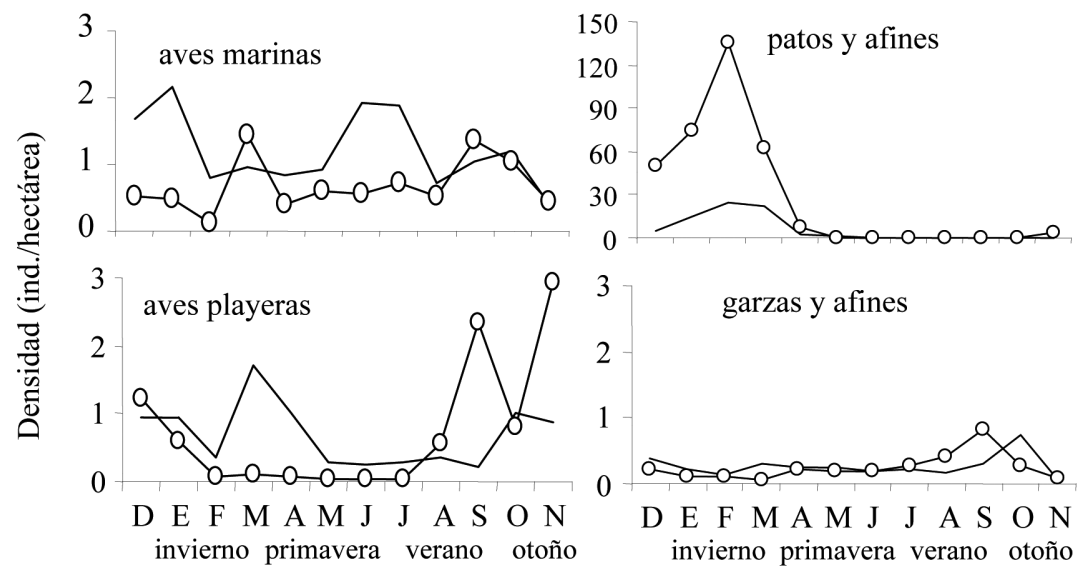

Fig. 2. Densidad de individuos de aves acuáticas en la launa de Agua Dulce $(\longleftarrow$ ), y el estero El Ermitaño ( $\multimap$ ).

Fig. 2. Individual density of waterbirds in the Agua Dulce ( $\square$ ), and El Ermitaño estuary ( $\longrightarrow$ - $)$.
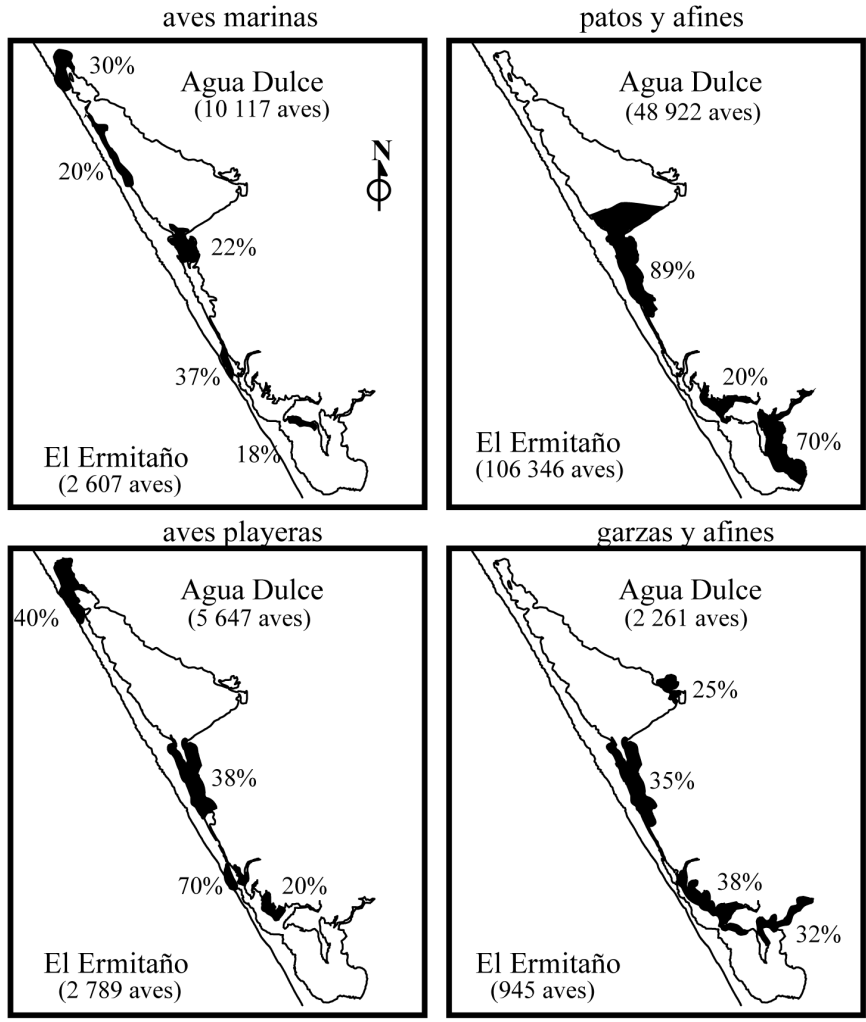

Fig. 3. Patrones de distribución de aves acuaticas en la laguna de Agua Dulce y estero El Ermitaño.

Fig. 3. Distributional patterns of waterbirds in the Agua Dulce lagoon and El Ermitaño estuary. 